\title{
Character Education of Openness in Regional Representative Body of West Java
}

\author{
Edwin Rizal \\ (Faculty of Communications, University of Padjadjaran, Bandung; edwin.rizal@unpad.ac.id) \\ Diah Fatma Sjoraida \\ (Faculty of Communications, University of Padjadjaran, Bandung; diah.fatma@unpad.ac.id) \\ Rully Khairul Anwar \\ (Faculty of Communications, University of Padjadjaran, Bandung; rully.kbairul@unpad.ac.id)
}

\begin{abstract}
Abstrak
Artikel ini menganalisis implementasi UU No. 14/2008 tentang Keterbukaan Informasi Publik (KIP; Keterbukaan Informasi Publik) dari Badan Perwakilan Daerah Provinsi Jawa Barat (DPRD; Dewan Perwakilan Rakyat Daerah). Penelitian deskriptif kualitatif ini menyajikan diskusi tentang pendidikan karakter dalam implementasi kebijakan tersebut di Provinsi Jawa Barat. Dengan teori implementasi kebijakan dan pendidikan karakter, diperoleh temuan bahwa elemen pendidikan karakter dalam implementasi kebijakan informasi publik di DPRD Jawa Barat cukup tebal dan efektif. Karena itu harus memasyarakatkan implementasi UU di Jawa Barat. Ditemukan juga babwa unsur-unsur pendidikan DPRD provinsi Jawa Barat dalam implementasi undang-undang ini dengan mendapat penilaian yang cukup baik di masyarakat. Namun demikian, kurangnya publisitas tentang UU KIP ini dapat mengurangi kekuatan pesan moral yang terkandung dalam UU kepada publik, yaitu tentang keterbukaan.
\end{abstract}

\section{Kata kunci: Implementasi Kebijakan; Keterbukaan Informasi Publik; Kebijakan publik; Jawa Barat}

\begin{abstract}
This article analyzes the implementation of Law No. 14/2008 on Public Information Openness (KIP; Keterbukaan Informasi Publik) of the Regional Representative Body of West Java Province (DPRD; Dewan Perwakilan Rakyat Daerah). This qualitative descriptive study presents a discussion of character education in the aforementioned policy implementation in the province of West Java. With the theory of policy implementation and character education, the data obtained that the element of character education in the implementation of public information policy in the DPRD of West Java is quite thick. Therefore it should massifize the implementation of the Law in West Java. It was also found that the educational elements of the DPRD of West Java province in the implementation of this law had got a pretty good
\end{abstract}


assessment in the community. Nevertheless, the lack of publicity about this KIP Law could reduce the strength of the moral message contained in the Act to the public, i.e. on the openness.

\section{Keywords: Policy Implementation; Public Information Openness; Public Policy; West Java}

\section{A. Introduction}

The Era of Reform has brought a paradigm shift in the system of government in Indonesia, where transparency as one aspect of good governance requires governance more open. The principle of transparency into the spirit of the democracy is to recognize the sovereignty of the people to be involved in any decision-making, implementation and social control in the process of government to serve public interests and implement the development. Through the spirit of openness (transparency), the state gives spaces to the public to have the access to information related to government-controlled public interests (Rahman, 2014). The spirit of transparency also requires the implementation of good governance, transparency and accountability.

The Constitution (UUD 1945) guarantees every Indonesian citizen to communicate and access information freely. To this, the government issued Law No. 14 of 2008 concerning public information openness (UU KIP). Here the Law pictures the government's commitment to open the entrance of public openness in Indonesia as well as the basis for the involvement of the public to know the process and rational decisions concerning the lives and public interests, processes of implementation and evaluation practices at every level of governance from central government to the regions. In order for the implementation of the Law goes well, 


\section{ARTIKEL}

every line of government bureaucracy both central and local levels should have a Regional Information Management Officer (PPID) and to establish Regional Information Commission (KID).

Following up the Law, the Government of West Java Province responded by forming KID and PPID that address the implementation of information services and public disclosure in the Government of West Java Province. In 2011 and 2012, the Government of West Java Province was awarded as the best public institutions in the implementation of public disclosure. Nevertheless, public information disputes in West Java are among the highest category compared to other provinces in Indonesia (Republika, June 27, 2012). In fact, the trend of conflict or dispute information in West Java had increased in this period. Their disputes show that the ministry of information and public disclosure in West Java province has not run properly.

The implementation of a policy is an administration tool, where various actors, organizations, procedures and techniques work together to run a policy in order to achieve the desired effect or purpose. The successful achievement of policy objectives depends mainly on the actors who participated in the implementation of the policy. Therefore, Michael Howlett and M. Ramesh (1995), Charles O. Jones (1984) and Gordon (1986) explains that the implementation of the policy can be seen as a process of strategic interaction that exists of cooperation between a large number of actors involved in the implementation of policies to achieve policy mandates. The participation of such individuals in the group policy application may have some forms and in collaboration with government agencies.

Public Information Openness becomes a necessity for all elements of society, for it is one of the prerequisite and foundation to create an open, good government. 
It is like the opinions expressed by Rodney A. Smollar (1992: 12): "A society that wishes to adopt openness as a value of overarching significance will not merely allow citizen a wide range of individual expressive freedom, but will go on step further and actually open up the deliberate processes of government itself to the sunlight of public scrutiny. In a truly open culture, the normal rule is that government does not conduct the business of the people bebind closed door. Legislative, administrative, and judicial proceedings should - as a matter of routine- be open to the public."

Good governance has a number of indicators including openness, participation, accountability, effectiveness and coherence. According to Mas Achmad Santosa (2011: 22), open governance requires a guarantee of five things:

1) the right to monitor the behavior of public officials in carrying out their public roles;

2) the right to obtain information;

3) the right to be involved and participated in the formation of a public policy;

4) freedom of expression, among others, is expressed in the freedom of the press; and

5) the right to appeal the denial of the right of the previous four.

In Indonesia, a policy of public disclosure (Law No. 14 of 2008) represents a new paradigm in governance. The publication of the law of public disclosure is a government's self-improvement effort to regain the trust of the public relating to information about the performance of government institutions. The Law formulates in detail the ways the implementation of public information disclosure. In the general provisions of the Law what is meant by public information is information generated, stored, managed, delivered and / or received by a public body relating to organizing 


\section{ARTIKEL}

and administering the state and / or organizer and organizing public entity in accordance with the Law and other information relating to the public interests.

However, the implementation of the Law of greater openness of public information was not always effective and achieved the objectives of the policy. Many terms, conditions and factors influence the effectiveness of the implementation of the policy. Hoogerwerf (1983: 157-161) says that the policy has such elements as: (a) the program of action; (b) the target group; and (c) the implementing elements.

Brian W. Hogwood and Lewis A. Gunn (Nugroho, 2008: 630-2) say that the elements for implementing the policy is not enough with three (3) elements stated by Hoogerwerf above. Policy elements require (1) adequate resources, (2) a deep understanding of agreement to the achievement of the objectives; and (3) the need of perfect communication and coordination.

Van Meter and Van Horn (in Parsons, 2008: 482) say that policy implementation is shown also by the presence of a high level of consensus and does not need many changes. The officers of the law including judges, prosecutors, police, and so on must have good mentality in implementing a legislation or policy. Because if there were otherwise, there will be disturbances or obstacles.

According to Hoogerwerf (1983: 157-161), the essential elements of policy implementation include (1) the action program; (2) the target group; and (3) implementing elements. Then the elements of the policy as outlined by Hoogerwerf complement the knowledge of the elements of a policy based on the opinion of Brian W. Hogwood, Lewis A. Gunn; and Gordon (1986).

On the one hand, policy elements are not only formulated and implemented to support the implementation of appropriate policies, but also influenced by factors 
beyond the earlier policy elements. Howlett (2019: 9-11) describes the factors that lead to successful implementation of policies including the variable policy content (content of implementation) and the policy environment variables (context of implementation).

On the other hand, Law No. 20 of 2003 on National Education System, Article 3, states that the national education serves to develop skills and form the character and civilization of the nation's dignity in the context of the intellectual life of the nation. National education aims at developing the potential of learners in order to become a man of faith and fear of God Almighty, noble, healthy, knowledgeable, skilled, creative, independent, and become democratic and responsible citizens.

Government Regulation No.17 of 2010 on the Management Education and Provision of Article 17 Paragraph (3) states that basic education, including junior high school (SMP) aims at building a foundation for the development of potential learners in order to become a human being. The characteristics of the human being are: (a) faithful and devoted to God Almighty, (b) noble, and noble personality, (b) knowledgeable, competent, critical, creative, and innovative; (c) healthy, independent, and confident; (d) tolerant, sensitive to social, democratic, and responsible. Accordingly, it is clear that the purpose of education at all levels including junior high school is associated with the development of the character of the learners.

Character education is not only a requirement of the laws and government regulations, but also a requirement of religion. Every religion teaches the character of the adherents. In Islam, morality is one of three basic frameworks that have a very important position, in addition to two other basic frameworks: the aqidah and the 


\section{ARTIKEL}

shariah. Prophet Muhammad in one of his saying hinted that his presence on earth is a mission essential to perfect the noble human character. The noble moral behavior that is required is a system of Islam through the texts of the Quran and Hadith. Special (moral) characteristics owned by Prophet Muhammad, the prophets and apostles are: (1) Siddiq, which means honest. Prophets and apostles are always honest in their words and behavior. (2) Amanah, which means that they can be trusted in their words and actions. (3) Tabligh, which means delivering what they received from God (revelation) to humankind. (4) Fatanah, which means smart of clever, so as to overcome all the problems they face. (5) Ma'shum, which means never to have sinned or in violation of God's law. As a human being the Prophet could have done something wrong and forget to make mistakes, but all of his mistakes always get warning from God that can eventually run in accordance with the will of God (Ghafran \& Yasmin, 2019).

The research at Harvard University in the United States (in Ibrahim Ali Akbar, 2000) showed that a person's success is not determined solely by the knowledge and technical skills (hard skills), but more by the ability to manage ourselves and others (soft skills). This research suggests that success is determined only about 20 percent by the hard skills and the remaining 80 percent of the soft skills. Even the most successful people in the world can be succeeded because more widely supported by the ability of soft skills than hard skills. Soft skills are the skills of someone who is more subtlety or sensitive to the feelings of someone on the surrounding environment. Given the soft skills are more directed to the skills of the psychological impact of a less visible but still can be felt. The consequences can be 


\section{ARTIKEL}

felt is the polite behavior, discipline, perseverance, ability to work together, helping others, etc. Soft skills are related to one's character.

According to Elkind \& Sweet (2004), character education understood as: "deliberate effort to help people understand, care about, and act upon core ethical values. When we think about the kind of character we want for our children, it is clear that we want them to be able to judge what is right, care deeply about what is right, and then do what they believe to be right, even in the face of pressure from without and temptation from within".

Character education is that teachers do everything, which could affect the character of the students. Teachers help shape the character of students. This includes how the exemplary behavior of teachers, how teachers speak or submit material, how the teachers have a tolerance, and various other related matters.

The New Education Policy should bring positive impacts on learning values in Indonesia. It means school as one of educational institution not only focuses on its academic system but also has a responsibility in developing character of the students. Brown stated good character is more to be praised than outstanding talent. Most talents are, to some extent, a gift. Good character, by contrast, is not given to us. We have to build it, piece by piece - by thought, choice, courage, and determination. Character is a complex system of habits that support or impede the development of a person's unique potential for excellence. Such a conception would require character educators to pay attention not simply to socially-sanctioned norms for behavior such as honesty and perseverance, but also and perhaps more importantly to the ways in which their students conceive of their own ideal selves, and the personal qualities that will support the actualization of those selves. This 
conception may require a more personalized or less formulaic approach to character education, but the rewards of such transformations of education are goals and methods might well be the revitalization of democratic society.

There are definitions of character. According to the American Dictionary of the English Language, character is ..."the stable and distinctive qualities built into an individual's life which determines his response regardless of circumstances." Mike Thomson Chairman of the It's All About Character organization, says, "In fact, the true test of good character is making good choices even when no one is watching."

Recognizing the importance of character, nowadays, many parties demanded an increase in the intensity and quality of the implementation of character education in formal educational institutions. These demands are based on a growing social phenomenon, namely the increasing juvenile delinquency in the community, such as the mass brawl and various other cases of moral decadence. Even in some big cities, these symptoms have been to the extent that very disturbing. Therefore, formal education institutions as forum for youth development of personality of students through increased intensity and quality of character education. So that learners have a noble character according to religious norms, laws, manners, culture, and customs, it is necessary to be done adequately character education.

Among the good character is behaving honestly. This behavior is based on an attempt to make himself as a person who always trustworthy in word, action, and work, both to themselves and others. This is where the Law of Public Information gains relevance. The Law is to bring the people of Indonesia in the atmosphere to be honest, especially on the officials. Thus, the implementation of this law at the government is a means of character education. 


\section{ARTIKEL}

E-ISSN: 2615-5028

According to T. Ramli (2003), the essence and character education has the same meaning as moral education. The goal is to establish a child's personality to be a good human being, society, and a good citizen. The criteria for good men and good citizens for a community or nation, in general is a certain social values, which are influenced by the culture of the people and nation. Therefore, the essence of character education in the context of education in Indonesia is educational value, namely education noble values sourced from Indonesian culture itself, in order to develop the personality of the young generation.

Based on the grand design that was developed by the Ministry of National Education (2010), psychological and social cultural character formation in the individual is a function of the whole potential of the human individual (cognitive, affective, and psychomotor) in the context of social cultural interaction (in the family, school, and community) and last a lifetime.

\section{B. Method}

This research on public information disclosure policy implementation is categoriez as a qualitative research. According to Taylor and Bogdan (2003), qualitative research done by observing the activity of a particular social group, which is in the observation activities of the group attempted to describe in detail the start of the process until the behavior of those who engage in such activity.

In practice, this qualitative research conducted was to assess and describe the public disclosure policy process implemention in West Java province with special attention to the process of policy implementation, especially on the elements of the 


\section{ARTIKEL}

administrators. The data used are primary data and secondary data. The primary data obtained through informants and sources consisting the implementor is an official policy of structural (PPID, public relations staff, staff diskominfo, commissioner KID) and the target groups (target group) the relevant institutions and public interest groups.

Qualitative research on the study of the implementation of the openness of public policy is also relying on data analysis, deductive directed at businesses observation of phenomena fundamental, on matters relating to the implementation of the policy of public disclosure, such as the importance of the process, how the policy was implemented, a set of elements attached to the policy (Anwar, R. K., A. Rusmana, and M. T. Rahman, 2018). The observations and data collected are then analyzed with the help of the theoretical framework that has been built.

This research of policy implementation related to public openness with a qualitative approach conducted objectively through direct observation, documentation and interviews. And when required to do the deployment of open questions, taking into account the terms of the evaluation instrument that includes the validity of the data (credibility and transferability), objectivity (confirmed), relevance, and ease of use in the crawling of the data.

\section{Results and Discussion}

The implementation of the policy of the openness of public information is closely related to the rapid development of technology and communication (ICT). Due to the structure of implementing organizations, should be prepared also human resources able to develop and utilize ICT (Anwar, Lusiana, and Rahman, 2019). 
According to the Head of Communications and Information Technology West Java Province, in an interview, the use and utilization of ICTs as the driving force of public services is still very low perceived. Although some organizations / institutions have already used ICT, they are still within a limited scope. Utilization of ICT is one perfect solution to solving the problem of public services that are difficult to overcome with conventional ways. Improving the quality of human resources through the development and utilization of ICT will help the performance of public services in an integrated manner, so as to realize an effective government management, efficient, transparent and accountable.

West Java Provincial Government must start with a sound management system and work processes are integrated or modernization in the administration of local government in order to apply the telecommunications, multimedia and information (telecommunications) appropriate so as to achieve the key objectives to increase public information services to the public, PPID success in providing access to information as mandated by the Public Information Service is one indicator of the transparency of government administration. PPID should not only be complementary to run the government's obligation to implement the mandate of the Freedom of Information Law, but is furthermore able to position themselves while running basic tasks and functions as instructed.

Local information commission (KID) of the province has not been fully exercised by the authority in terms of providing policy support to the Government of West Java province in the form of general policy, the implementation of the technical guidelines of public disclosure, as mandated by the Law. According to Riant Nugroho (2008: 618-619), the implementation of the policy in principle is a way for a 


\section{ARTIKEL}

policy to achieve its objectives. To implement the policy needs to make a derivative of the public policy. Public policy in the Act or regulation is a type of policy that requires public policy descriptors or often termed as the implementing regulations.

Although in the public information services KID Province has been adhered to the Per-KI SLIP (Regulatory Information Commission Public Information Service Standards) and PPSIP (Procedure Settlement of Public Information), but KID province should also make implementation guidelines and technical guidelines public information services tailored to local conditions in West Java province. In addition, in preparation categories and classification of the information available at any time, immediately, periodically, and the information is exempt, KID province needs to help guide the preparation of PPID in the category and classification of the information. Do not let any divergence, when PPID categorize information as information that is excluded but the settlement of disputes, the information is even said to be information that is open and accessible at any time. Therefore, there must be clarity and agreement between the Province KID PPID associated with the classification of the information.

The development of information classification must always be monitored by the KID Province. Because according to Article 20 of the Law of KIP, exempt information will not be permanent. This means that if an agreed-upon time and does not threaten national security the information originally excluded could be turned into information that can be accessed at any time.

KID of West Java should be intermediaries capable of uniting an understanding between the government and the public on the matters of public information access rights disputes. Commission information is not only the party 


\section{ARTIKEL}

that defends the rights of the public and or siding government administrative work in terms of the completion of the dispute. KID of West Java should portray themselves as the party that is in the middle of solving problems related to access to information between the public and the government. Commission information is also supposed to be a confirmation of the public limit their rights to access information (Hikmat, 2013: 124).

In terms of the methods of KIP policy implementation in West Java using a decentralized pattern in which the public information services directly implemented by the Local Implementer Organization (OPD; Organisasi Pelaksana Daerah) respectively is already quite effective in serving each request for public information. However, this decentralized method becomes less effective when not socialized properly in society. With decentralization methods, the community wishes to make a request for information if the public should be directly facing the PPID that pursuant to the authority of the OPD where PPID is located.

People, who are not properly socialized regarding this decentralized method, generally apply their wishes directly to Gedung Sate by contacting Public Relations West Java Provincial Secretariat. Although the request for the information was submitted to the Local Secretary of the government to Local Office for Communication and Information (Diskominfo), then from Diskominfo freshly delivered to the OPD related to follow-up, but for people who do not understand, often complain that the request for public information addressed to the Government of West Java Province impressed throwing the responsibility of public information services, Yet what is done either by the Public Relations of the Regional Secretariat and Diskominfo was appropriate, because the OPD cannot provide the information 


\section{ARTIKEL}

E-ISSN: $2615-5028$

that they do not speak, as if still provide information that is not controlled by the real is the authority of the OPD else, if doing so would violate the provisions of Freedom of Information Law. This provision is in accordance with Article 6 Paragraph (3) letter (e) Freedom of Information Law which states that public information cannot be provided by a public agency, if the public information requested is not controlled or documented.

Based on these issues, there is a lack of decentralization, namely the application of a lack of socialization in the community about the mechanism of public information requests. Although the Government of West Java province has socialized procedure for requesting information but the West Java Provincial Government does not explain the public information lists what is available in each of the OPD. Unavailability of public information in each OPD, serve as guidelines / directives for the public to know the available public information requests every OPD destination.

Although the application is deemed effective decentralization patterns, but some of the considerations mentioned that the pattern of decentralization is not secure enough, because even though the state (government) guarantees the right of public access to public information widely, but basically these access rights are sometimes limited. Restriction of access rights when it comes to information that is excluded for the sake of keeping state secrets and national security. Therefore, decentralization patterns are applied in West Java province is quite risky because of the application of this pattern becomes uncontrolled information flow. Each OPD may have a standard policy and public information services different so it will be a new source of conflict. 
There is a good proposal for a pattern of centralization in public information services in West Java Provincial Government may be applied. Due to the centralization pattern, Governor has been easier to monitor any information flowing to the public. If this centralization pattern is applied then there is a need for a hybrid structure between the existing structures in the secretariat area and in the OPD OPD-other. The implementation of this centralization real pattern is in accordance with the mandate of UU KIP. Freedom of Information Law requires every public body has a PPID in PPID boss (Article 35; Article 36; Article 37; and Article 46 UU KIP). PPID boss here who will be responsible for all the decisions PPID helpers (in each OPD) and respond to objections submitted by the applicant is public information.

During this time the West Java Provincial Government by adopting a decentralized, where requests for information are handled directly by the respective OPD, the province of West Java Province has no real PPID important role as boss of PPID in each OPD. Supposed to be any good public information method of service using a pattern of decentralization or centralization, PPID boss must still be formed to keep communication and coordination in the West Java province in implementing public information service run smoothly. The pattern of this decentralization will be successful if the service authority information given to each of the OPD, supported by the Provincial PPID (as an umbrella of PPID) that is authorized to conduct coordination, communication, and establishes general policies related to public information so that the standards of service in each OPD becomes uniform. The existence PPID province also intends to carry out the functions of control over the flow of information that is dispersed into the community. 


\section{ARTIKEL}

E-ISSN: $2615-5028$

PPID provincial superiors should be held by officials of echelon II. Subagiyo (2009: 316) saw duty supervisor PPID associated with decision-making and have legal consequences severe enough, then the superior officer should be an official who has high enough rank. In many discussions conducted by the author with officials of public bodies, officials referred boss should echelon II.

PPID is an ad hoc provincial office that contains elements of the public relations department, the legal department, department of communication and information, which assisted in coordination with other OPDs. Public Relations Section as PPID Province in cooperation with the Office of Communications and Information, while the Legal Department in charge of providing legal considerations related to test consequences of exempt information and giving legal if there is a lawsuit objection of the applicant to public information.

\section{Conclusion}

The Law of Public Information Openness has shown a good coaching national character, that is honesty. Thus, the practice of this Act can be brought on character education, especially to the younger generation. These interests are perceived in the West Java administration.

However, there are some shortcomings in the process of policy implementation Public Information in West Java Provincial Government Environment. Among them are the unity of coordination and uniformity of information services, as well as cooperation in the agency network PPID, in the Provincial Government of West Java has not been implemented because of structural 
problems hampered. Moreover, the implementing agency are less motivated by matters of public information services remains a sideline function is not the main function in the duties and functions of the regional organization (OPD) so that there is no rewards in the form of performance calculations.

\section{BIBLIOGRAPHY}

Anwar, R. K., A. Rusmana, and M. T. Rahman. "The Politics Of Information On Traditional Medical Practices In Bandung Barat. MIMBAR." Jurnal Sosial dan Pembangunan 34, no. 1 (2018).

Anwar, Rully Khairul, Elnovani Lusiana, and Mohammad Taufiq Rahman. "Internet Advertising and Consumptive Lifestyle of the Students." TEMALI: Jurnal Pembangunan Sosial2, no. 1 (2019): 46-60.

Bandung Ekspres, Birokrasi Pemprov Saling Lempar, Kamis, 29 September 2011.

Dye, Thomas R. Understanding Public Policy.Toronto, Canada: Prentice Hall, 1995.

Ghafran, Chaudhry, and Sofia Yasmin. "Ethical Governance: Insight from the Islamic perspective and an empirical enquiry." Journal of Business Ethics (2019): 1-21.

Gordon., I. \& J. Lewis. Perspectives on Policy Analysis. Public Administration Bulletin, Vol. 25, 1986. 


\section{ARTIKEL}

Hikmat, Mahi.M (ed). Potret Keterbukaan Informasi Publik: Pemikiran dan Gagasan dari Jawa Barat. Komisi Informasi Provinsi Jawa Barat., 2013.

Hoogerwerf. Ilmu Pemerintahan. Jakarta: Erlangga, 1983.

Howlett, Michael and M. Ramesh. Studying Public Policy: Policy Cycles and Policy Subsystem. New York: Oxford University Press, 1995.

Howlett, Michael. Designing public policies: Principles and instruments. Routledge, 2019.

Jones, Charles O. An Introduction To The Study Of Public Policy, Monterey, California; Brooks/Cole Publishing Company, 1984.

Keputusan Gubernur Provinsi Jawa Barat Nomor: 489/Kep.486-Diskominfo/2010.

Mariana, Dede. Ilmu Pemerintahan. Pusat Kajian Pemberdayaan Desa, 2011.

Meter, Van dan Horn. Van. Human Resource Champions. Boston: Harvard Business School Press, 1974.

Miles, Matthew dan Huberman, A. Michael. Analisis Data Kualitatif: Buku Sumber Tantang Metode-Metode Baru. Jakarta: UI Press, 1992.

Nugroho, Riant. Public Policy: Teori Kebijakan, Analisis Kebijakan, Proses Kebijakan, Perumusan, Implementasi, Evaluasi, Revisi, Risk Management Dalam Kebijakan Publik, Kebijakan sebagai The Fifth Estate, Metode Penelitian Kebijakan. PT. Elex Media Komputindo, Jakarta, 2008.

Parsons, Wayne. Public Policy: Pengantar Teori dan Praktik Analisis Kebijakan, Jakarta: Penerbit Kencana, 2008.

Pikiran Rakyat, Keterbukaan Informasi (Jangan) Sekadar Basa-Basi, Kamis, 29 September 2011.

Rahman, M. Taufiq. Social Justice in Western and Islamic Thought: A Comparative Study of John Rawls's and Sayyid Qutb's Theories. Scholars' Press, 2014. 


\section{ARTIKEL}

E-ISSN: 2615-5028

Republika, Kasus Sengketa Informasi Jabar Tertinggi, 27 Juni 2012.

Santosa, Mas Achmad. Good Governance dan Hukum Lingkungan, Jakarta: ICEL, 2011.

Seputar Indonesia, Mayoritas Badan Publik Pemprov Tertutup, Kamis, 29 September 2011.

Smollar, Rodney.A. Free Speech in an Open Society. New York: Vintage Book, 1992.

Taylor, Steven J. and Bogdan, Robert. Introduction to Qualitative Research Methods. $5^{\text {th }}$ edition. Hoboken, New Jersey: John Wiley and Sons Inc., 2003.

Tribun Jabar, Pemprov Jabar Belum Siap Terbuka, Kamis, 29 September 2011. 